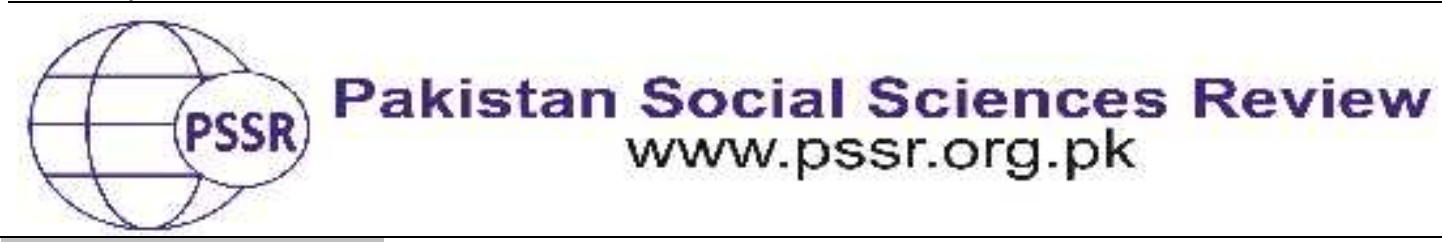

RESEARCH PAPER

\title{
Political Discourse Analysis of the Islamic Identity in Pakistan's Foreign Policy
}

\author{
Hamid Iqbal $^{*}$ Dr. Muhammad Hanif Khalil ${ }^{2}$ Umar Sohail 3
}

1. Lecturer, Department of International Relations, National Defence University, Islamabad, Pakistan

2. Associate Professor, National Institute of Pakistan Studies, Quaid-i-Azam University, Islamabad, Pakistan

3. Independent Researcher

\begin{tabular}{|c|c|}
\hline PAPER INFO & ABSTRACT \\
\hline $\begin{array}{l}\text { Received: } \\
\text { March 21, } 2021 \\
\text { Accepted: } \\
\text { May 30, } 2021 \\
\text { Online: } \\
\text { June } 05,2021\end{array}$ & $\begin{array}{l}\text { Identity, being a construct of social and historical milieus, by } \\
\text { the establishment of the differences between 'self' and 'others', } \\
\text { effects individuals or groups who tend to identify themselves } \\
\text { with that identity. Identity plays an instrumental role in } \\
\text { establishment of perceptive similarities with some actors while }\end{array}$ \\
\hline $\begin{array}{l}\text { Keywords: } \\
\text { Discourse } \\
\text { Analysis, } \\
\text { Identity, Islam, } \\
\text { Pakistan's } \\
\text { Foreign Policy }\end{array}$ & $\begin{array}{l}\text { history since independence in 1947, Pakistan has confronted a } \\
\text { constant identity crisis. However, in the face of an existential } \\
\text { threat emanating from India, Pakistan's power elite has } \\
\text { managed to tread the foreign policy of Pakistan using the } \\
\text { Islamic identity. This article discloses the discursive patterns of }\end{array}$ \\
\hline $\begin{array}{l}\text { *Corresponding } \\
\text { Author } \\
\text { hamidiqbal@nd } \\
\text { u.edu.pk }\end{array}$ & $\begin{array}{l}\text { identity and the role of discourse as a performative tool in } \\
\text { embedment of Islamic component in Pakistan's foreign policy } \\
\text { and how it helped shape the external outlook of Pakistan vis-à- } \\
\text { vis not only the Islamic world but also great powers. }\end{array}$ \\
\hline
\end{tabular}

\section{Introduction}

Pakistan soon after its independence defined its identity on three basic elements; Islamic identity, hostility towards India and Urdu. The national language of Pakistan was decided to be Urdu; in an effort to create a sense of nationhood among diverse ethnic communities, to stabilize internal cohesion and to avoid discrepancies on linguistic lines. The left over, 'ideological outlook and opposition to India', are of greater importance in terms of internal stability and external relations.

The Islamic component greatly influenced Pakistan's foreign policy towards the Muslim world. It acted as a source to shape and justify endeavors of power elite in Pakistan towards the Muslim world. This Islamic ventures with its 'Pan-Islamic' foundations greatly affected Pakistan's foreign policy towards the Muslim world. It was a realization on the part of the power elite in Pakistan to achieve the idea of 
Muslim brotherhood in political, economic and security domain and also to make it more meaningful.

The idea behind this discourse was two-fold, first to justify the foundation of Pakistan on Islamic identity and keep it distinct from 'Hindu' India and second to help power elite in the pursuit of its political interests without any hindrance. At the same time, in post-independence era, the anti-communist 'Jihad' also contributed to the Pan-Islamism outlook of the country. Nevertheless, it was the prevailing regional and international structure that shaped and played role in defining Pakistan's foreign policy on ideological frontiers.

\section{Constitutionalisation of Islamic Identity}

Since independence, Pakistan always prioritized the Muslim bond of brotherhood. The induction of identity was a necessary instrument of Power elite to get legitimacy and to sustain their privileged position in domestic sphere and to establish and justify foreign relations of Pakistan. The power elite made foreign policy preferences and checked its consistency with the established identity of Pakistan and then investigated it though the intelligent use of dominant discourse to satisfy the popular demands and sentiments.

In its first Constitution, Pakistan was declared as an 'Islamic Republic' in 1956. The constitution also laid down the foundation of fraternal relations with Muslim world as "the state shall endeavor to strengthen the bonds of unity among Muslim countries" (Article 24 of The Constitution, 1956; Choudhury, 1969: 103).Henceforth, every political party till now declared to strengthen their relations with the Islamic world.

Even the Awami League (AL) of East Pakistan went a step further at "bringing together the Muslim nations of the world and advocated the necessity of a world order based on the principles of Islam" (Civil and Military Gazette, March 19, 1950). During his visit to Pakistan, Saudi King, Saud ibn Abdul Aziz stated that, "there will always be strong ties between Saudi Arabia and Pakistan in peace and adversity...We are one and united" (Dawn, April 17 1954). These suggestions are clear indication that the Muslim elite in Pakistan articulated and justified Pakistan's foreign policy on ideological dimensions which was important to establish a stable link between a particular decision and basic discourse in understanding a particular phenomenon.

Along the 1962 Constitution of Pakistan the 1973 Constitution has not only given more prominence to Pakistan's relations with the Muslim world, but also to international peace and stability and the settlement of international disputes peacefully, friendly relations with all nations and Pakistan's support for the common interests of Asian, African and Latinos. However, Pakistan, through its constitution, has always given importance to the Muslim World that in return supported its foundational claim on ideological lines. Article 40 of 1973 states that, "The State shall 
endeavor to preserve and strengthen fraternal relations among Muslim countries based on Islamic unity..." (Article 40 of the Constitution, 1973).

\section{Pan-Islamism in Pakistan's Foreign Policy}

Islamic led identity, with its Pan-Islamism outlook remained a dominant and preferential component of Pakistan's foreign policy. Chaudary Khaleeq-uz-Zaman, the then president of All India Muslim League (AIML) identified that "Pakistan's foreign policy would be directed to bring all Muslim countries together into 'Islamistan' (trans-national entity)" (Siddiqi, 1960). In order to pursue this objective, Pakistan in 1949, hosted the 'World Muslim Conference' in Karachi which was outlined by the pursuance of Pan-Islamism agenda. The active and successful diplomacy of Pakistani leaders resulted in the establishment of the 'Moatmer al Alamal-Islami' (Muslim World Conference) (Siddiqi, 1960).

In addition, Ghulam Muhammad in 1949, suggested an Islamic organization for collective bargaining and collective security system for the Muslim states around the world (Haqqani, 2016). This was an indication that Islamic component was one of the vital source of Pakistan's foreign policy, if not like equal to the dictates of Indian hostility towards Pakistan, which became raison d'être of Pakistan's creation. It acted as a dominant source through which foreign policy decisions drifted and masses were not only convinced but also favored decisions of the power elite. Even, the pre-partition Muslim League's leadership raised their concerns about the treatment of Palestinians.

Pakistan placed itself in the glorious past which was related to its present, to discover its meaning and legitimacy of existence. Smith has put Pakistan's approach as, "Pakistan acquired independent statehood with a growing awareness of its belonging to a community that dwelled all over the globe right from Singapore in Asia to Morocco in Africa" (Smith, 1957: 204). The path to be part of the Muslim World adopted by Pakistan's power elite was as a clear manifestation of a renewed sense of belonging since its inception.

The same argument has been given by Callard to understand Pakistan's approach towards the Muslim World. If we analyze critically then Pakistan's tilt towards the Muslim World, in the greater context of Indian hostility since inception, become meaningful (Callard, 1957).Thus, it was the Indian fear of domination that Pakistan sought fraternal relations with Muslim World on the basis of ideological affinity which was also put forwarded by Golam Wahed Choudhury, a diplomat from erstwhile East Pakistan (Choudhury, 1969).

Pakistan from the day first championed the cause of Muslim plight and raised its voice for the right of self-determination of Muslims around the world in order to keep affiliations alive with the Muslim world and also a realization on the part of Pakistani elite to reinstate their ideological connection with the Muslims from around the world. Pakistan raised its voice for Muslims of Palestine, Indonesia, 
Tunisia, Morocco, Algeria and Libya both inside and outside United Nations (UN). Emphasizing the Palestinian Muslim plight, Hassan opined that, "With the exception of the Kashmir question, no issue that has come up before the United Nations has so stirred the people of Pakistan, or has called forth such exertions from its representatives as the question of Palestine" (Hassan, 1960: 165).

In addition, on the eve of joining the 'Baghdad Pact' (1955) known as Central Treaty Organization (CENTO), a pro-Western defense alliance between Turkey, Iraq, Iran, Pakistan, and the United Kingdom, while explaining Pakistan's decision to join Baghdad pact, Ayyub Khan stated that, "...the decision of Muslim world to join hands with the Christian world would benefit the former to materialize its PanIslamic leanings" (Khan, 1967: 154-55).

During 1965 Indo-Pakistan War, Pakistan won favor of some Muslim states like Iran, Turkey, Indonesia and others which were further consolidated in late 1960s with establishing cordial relations with Saudi Arabia. This time it was the Palestine issue on which Pakistan provided support to Arab countries after the Jerusalem Mosque incident in 1967. After this Pakistan also became the founding member of Organization of Islamic Cooperation (OIC) and thus Pakistan won the diplomatic and political victory to be part of greater Muslim world. However, currently the Middle Eastern countries have less affection for Pakistan while their evolving economic and strategic alignment and interests with India, seem a failure of Pakistan at diplomatic front.

Soon after the disintegration and the creation of Bangladesh in 1971, Pakistan channelized all the energies towards Indian hostility. Pakistan attempted to delink itself from India and to make itself a part of Islamic world. It was the time when there was an oil boom in the Middle Eastern countries. Z. A. Bhutto, an astute politician, utilized his diplomatic skills and personal charisma to cash the Muslim card in establishing favorable relations with these countries. Bhutto not only succeeded to send thousands of worker and professionals to Middle East but also later on, hosted the second OIC Islamic Summit at Lahore, Pakistan in 1974. In later years General Zia, persistently promoted the institution of Muslim 'Ummah'. Saudi Arabia became a role model for his own Islamic system known as the 'Islamization of Pakistan'. These close ties with Saudi also led the country to strengthen Islamic version of identity (Muzaffar, et. al. 2017)

Zia, after the Soviet involvement in Afghanistan called on both the UN meetings and OIC summit. In OIC Summit of January 1981, General Zia reiterated and established firm relations with the Saudi led Arab states using the religious card once more. Zia stated that:

"The Islamic World faced today new challenges...new dangers were being created which threaten the sovereignty and independence of the Muslim-States. The first Qibla of the Muslims was under alien occupation, ....... Palestinian refugees were deprived of their just rights, Iran continued to face threats, and there was a massive presence of foreign troops in Afghanistan." (OIC Resolution, 1981) 


\section{Finding Historical Affinities with Central Asia}

The Soviet collapse gave birth to the emergence of the Central Asian Republics (CARs). It inspired Pakistani intellectuals and policy circles to establish relations with CARs on the basis of cultural and historical affinities. Articles were produced, both in newspapers and journals along the establishment of Central Asian Studies Centers. Even it was proposed to declare Persian as an official language along $U r d u$ for strengthening cultural and political bond and also to reinstate the concept of Muslim brotherhood.

These cultural and ideational factors of Pakistan's foreign Policy frequently played a dominant and definitive role in determining the national security environment at regional, extra-regional and international levels which one to be perceived as its enemy or friend and ally. Katzenstiein has supported this argument that "definitions of identity that distinguish between 'self' and 'other' imply definitions of 'threat' and 'interest' that have strong effects on national security policies" (Katzenstiein, 1996).

\section{Relations with Iran}

Since inception, Pakistan has enjoyed very cordial relations with Iran for more than three decades. Iran was the first country to recognize Pakistan officially as an independent state. Due the cordial nature of relationship between Iran and Pakistan, the former, was boosted as the mother of Pakistani culture and Persian as the mother of its national language, Urdu (Burke, 1973). In case of Iran, the power elite used the ideological card to achieve national objectives of Pakistan's foreign policy. While naming Raja Ghazanfar Ali Khan as ambassador to Iran, Mr. Jinnah directed him to forge fraternal and everlasting relations with Iran based on genuine respect to each other (Majlesi, 2011). Further, Ayub Khan, while addressing the Iranian Parliament in 1959 stated that, "historically we have been one nation in the past, geographically we have a common border, and ethnologically we are of the same stock ... our links are steeped in history" (Pande, 2011).

Pakistan also resolved its border dispute with Iran, amicably in 1958 and the final protocol on Pak-Iran Boundary Award was exchanged in August 1960. Similarly, the appointment of Nasrullah Entezam of Iran as Pakistan's nominee on the Run of Kutch Tribunal was another gesture of trust and reliance of Pakistan on Iran in its approach to international disputes (United Nations, February 19, 1968). The relations between Iran and Pakistan remained smooth and based on trust till the advent of Iranian revolution. For the next two decades the relation remained strained and thorny due to internal changes in political setups along their approaches towards the region and beyond.

Iranian revolution was interpreted as 'Shai's' ideological expansion in Pakistan and had to be countered. Second most important was General Zia tilt towards Saudi Arabia and wished to implement Saudi Style Islamization in Pakistan. 
Third factor was Pakistan good versus Iran bad relations with America. Lastly, Zia in order to get legitimacy for himself exploited the religious card. These and other factors contributed to sectarian rift in Pakistan that can be felt even today especially in width and breadth of Pakistan. Then in 1990s, on the onset of Afghanistan, Pakistan supported once the sanctified worriers known as Taliban, a hardcore and pure 'Deobandi' brand of Sunni Muslims. The massacre of Hazara Shia community in Mazar Sharif including the killing of nine Iranian diplomatic personal widened the gap between Pakistan and Iran.

Then 2000s onward the most important event was the Iranian Chabahar Port construction and development, handled by India. It was perceived in Pakistan as a security threat to the survival of Pakistan, dominated by the Indian fear of encircling from the West along the already volatile situation in the East. Furthermore, along hostile relations with India, RAW operations inside Pakistan from Iran had also contributed to mistrust between Iran and Pakistan. However, scholars believe that main reason of mistrust is Pakistan's fraternal relations with puritanical Saudi Arabia on ideological frontiers. Though in reality Pakistan has always preferred Saudi Arabia due to its economic and energy potential. In addition, the international sanctions over Iran especially by the US, forced Pakistani power elite away from Iran.

\section{Turbulent Relations with Afghanistan}

Afghanistan, soon after the partition, was reluctant to recognize Pakistan as a UN member for a brief period due to its irredentists claim over Pakistani territory and its historical ties with India. This connection led to mistrust and more provocation among Pakistan power elite. In order to dilute the disturbance Mr. Jinnah stated that Pakistan and Afghanistan were like "two sister states" and hopefully they would have the 'greatest and everlasting relations' (Dar, 1986). The word 'sisterly' was an indication of Mr. Jinnah to remind Afghanistan that we shared the same geography and ideology and should have eternal relations instead of hating.

Likewise, Liaquat Ali Khan used the language of morality while Bhutto used religion to bring Afghanistan closer. Ayyub Khan also repeated his predecessor language and relied on the notion of Islam and ideology shared by both. However, he also established connection between Afghanistan and India as friendly and at the same time reminded Afghanistan that Pakistan was a reality and no one could undo it. In one of his statements about Afghanistan, he used the word "Pincer" (Khan, 1967) to draw parallels between history and present day military strategy that Indian adopted to have good relations with Pakistan's neighbors, to encircle it.

Khan on many occasions reinstated the Indian factor behind Afghan hostility towards Pakistan, and called on Afghanistan to consider the common Muslim identity as a foundation for friendly relationship between both. He said, "We share the same faith with our brethren in Afghanistan and this alone should prove decisive in providing basis for god relations" (Khan, 1967). 
During Zia's time Soviets intervened in Afghanistan which became a great source of concern for Pakistan. This also changed the Pakistan attitude towards Afghanistan and approached for help and established connections with the Muslim and Western world. It was the perceived Soviet intrusion that compelled Pakistan to look for all available options to defend itself. In 1980, Zia expressing his gravest concern over the Soviet involvement in Afghanistan said that "if Pakistan cannot defend itself, then Pakistan has no bloody right to exist. Short of getting foreign troops on Pakistani soil, the allies and friends of Pakistan must help us to stand on our own feet, economically and militarily".

It was the fear of Indian domination and to avoid future Afghan rivalry that led Pakistan to the so called conception of 'Strategic depth' (Pande, 2011: 61), in 1980s and later on, to their support to Taliban in 1990s both by the Nawaz government and the Benazir government, till the US invasion of Afghanistan in the pretext of terrorism. The state policy was to support Taliban, even Nasirullah Babar used to call them as "our boys" (Takkar, 2016). In addition, former Foreign Minister Abdul Sattar also supported the Taliban by creating a stable link between them and calling them "Mujahidin' (the holy worriers) (Sattar, 1997). Ideology/identity and domination by India remained the central tenants of Pakistan's foreign policy towards Afghanistan. It is still playing a role in shaping its foreign policy.

\section{Strengthening Relations with Turkey}

Another Muslim country with which Pakistan developed its relations by appealing to culture and ideology was Turkey. The relations were traced back to the Ottoman Empire and the Indian Muslims' response to its decline during the WW-I. This support of Indian Muslims was followed by a positive perception of Turks after the creation of Pakistan. Pak-Turkey diplomatic relations were established soon after its birth, which resulted in establishing cultural, religious and economic relations. Mr. Jinnah idealized and praised the Turks for their bravery and sacrifices for the struggle to attain and maintain its independence in the post-WW-I, while showing great sentiments of affection towards them. ("On Spiritual," 1989).

Since inception till Musharraf, Pak-Turkey relations restricted mostly to cultural and economic ties. However, the changing pattern of power elite perceptions led to more cordial relations since 2000s onward. Since the onset of President Erdoğan in Turkey, their relations have been forged in more ideological stepping. Here, again Pakistan consulted to its constituted Muslim identity and hostility to India and garnered Turkey's support on its stance over Kashmir issue (Kowalski, 2019).

\section{Pakistan's Quest for Security: Pak-US Relations}

Soon after independence, Pakistan was in search of friends in order to mitigate internal problems and to fight back against the mighty India by appealing to identity discourse. Religion was again used to get closer to the US and to distance 
Pakistan from communism. Mr. Jinnah stated on September 7, 1947 that "communism does not flourish in the soil of Islam," adding that Pakistan's interests align better with USA and the British (Kux, 2001).

The same notion was adopted by Liaquat who tried to project Islam's comparison and Christianity by contrasting it with Hinduism by stating that, "the Muslims were monotheist, the Hindus were polytheist" (Khan, 1950). Liaquat tried to draw attention towards Islam's greater religious compatibility with Christianity vis-à-vis Hinduism.

The joining of SEATO was a triumph for Pakistan as now it came closer to the U.S. to bargain for military and economic assistance. Pakistan's official stance was supportive of the West during Ayyub regime. The 'Treaty of Friendship and Commerce' signed during Ayyub's visit to the U.S. in 1959, followed by President Eisenhower's visit to Pakistan in 1960, brought two countries closer. These mutual visits were applauded by Dawn Newspaper that, "the U.S. and Pakistan, hound by common ideals, present a strong and unified position in the face of external threats" (Hussain, 1996).

Zia's rise to power, followed by the Soviet invasion of Afghanistan brought the U.S. and Pakistan even closer to each other. Zia appealed and used the identity card to take on board Muslim and Christian worlds. Internally, he adopted the 'Islamization' process to keep the masse happy and on his side while at international front he adopted anti-communist stance. After him, both Benazir Bhutto and Nawaz Sharif tried to have good relations with the U.S. but they failed to do so owing to their continuous pursuance of nuclearization path. Nevertheless, with Pervez Musharraf's rise to power, and the subsequent terror attack of 9/11, Pakistan's power elite was compelled to revisit its foreign and domestic policy.

The 9/11 attacks compelled the U.S. to take decisive measure against terrorists, especially Al-Qaeda. The Neocons-led world order also gave birth to a new metropolitan discourse that resulted in the division of world into pro versus against America. Pakistan supported the Taliban regime since they took power in Afghanistan due to ideological affiliation and a friendly neighborhood policy. Under this changed circumstance, Pakistan was faced with another challenge. Notwithstanding its ideological affiliations, Pakistan could not face international pressure thus decided to join the Global War on Terror, despite mounting public resentment. The decision also helped Musharraf to legitimize his unconstitutional martial rule and to persuade Bush to find a solution to the Kashmir issue.

Under these circumstances, Musharraf tried to articulate his foreign policy decision in the language of identity. He tried to articulate his decision through the prism of Indian threat and Islamic ideals. In one of his speeches he stated that, "let's look at our neighbors. They have promised U.S. all cooperation. They want to isolate us, get us declared a terrorist state. Further, to make the discourse more acceptable he used the language of security to safeguard national interests especially the Kashmir cause, through statements such as "Pakistan had to assist the United States; 
otherwise four vital interests of Pakistan would be in jeopardy - its sovereignty, its economy, its strategic assets, and its cause in Kashmir" (Jones, 2004).

Furthermore, to counter the mounting pressure of religious groups domestically, he took refuge in religious discourse to make it more effective and linked it to the early era of Islam when the Muslims were less and weak. He also tried to establish a link between his decisions to walk out from 'Taliban' with the decision of Prophet (SAW) to do 'Hijrat' (Migration) and get strength. He stated that, "Some 'Ulema' are trying to react on pure emotions. I want to remind them of Islam's early history. They moved from Mecca to Medina (Hijrat). Was this (God forbid) cowardice? This was wisdom to save Islam

Furthermore, Musharraf introduced a new idea of 'enlightened moderation' in order to counter the domestic resistance and also to find place in the dominant international discourse. At domestic side, it was meant to get rid of the 1980s and 1990s 'Jihadi' discourse and anti-Americanism while at international side it was propagated to get rid of the image of supporter of international 'Jihad'. This proposed discourse was based on deploring the confrontational approach towards the West.

In support of his new discourse he stated that, "the armies of Islam did not march forward to convert people by the sword, despite what the perceptions may be, but to deliver them from the darkness through the visible example of their virtues." Further, he suggested tolerance as an alternative to violent confrontation (Musharraf, 2004). He also suggested remedies for the miserable lives of Muslims around the world and that was through the adaptation of 'enlightened moderation'.

This discourse worked well at international level as it not only helped in detaching Pakistan from Islamist states but also constructed a new image of Pakistan to be reckoned by international community and to provide religious cover to avoid any resistance from religious strata internally. However, at domestic level, the religious interpretation was different due to the past legacy of 1980s and 1990s where masses accepted anything from 'Molvis' without giving it a second thought. For religious section of the society, Pakistan's alliance with America was fanaticism and against the teaching of Islam. This different interpretation from Islamists, led to violent resistance against the state. Consequently, state has to fight back and started a war against the so-called Islamists. Till the APS terrorist attack in 2014, public was largely divided and confused to follow either side.

The attack led to the development of a new discourse by the power elite that clearly drew line of demarcation between the fundamentalists and militant on one side, and pro-state on the other. The new discourse projected these fundamentalists as un-Islamic, brutal, amoral and inhumane etc., and to fight against them was in accordance to the teachings of Islam. Furthermore, steps were taken to link terrorists with India. They were declared as pro-India and were then denounced as anti-state and disloyal. Despite all these ground realities, Pakistan was divided on religious 
lines and for power elite, Islam was still relevant in mobilizing public opinion to pursue their interests.

\section{The Israel Question}

Israel played a dominant role in Pakistan's foreign policy. Since inception, Pakistan has never recognized the state of Israel. Pakistan-Israel relations never remained friendly due to Pakistan's Islamist outlook and support for the Islamic world in solidarity with Palestinian Muslims. The most important aspect of these thorny relations is Indo-Israel friendly relations particularly in security domain. During Jinnah's time, Pakistan was in favor to send former military soldiers to Palestine to fight for the cause of Palestinian and to prevent the emergence of Israel (White, 1949).

The second and most important aspect was described by Zia in 1980, that, "Pakistan believed Israel's close ties with India reflected an organized conspiracy against Pakistan" (Kaufman, 1980). The same narrative was repeated by Pakistan's Foreign Office Spokesperson, who stated that the 'India-Israel nexus' posed a "serious threat to regional security" and stressed the need for countries in the region to "demonstrate utmost circumspection" on this account, especially in the wake of prevailing nuclear environment in the region (Pande, 2011). Pakistan's Islamic outlook still dominates its relations with Israel irrespective that some internal segment along GCC countries wishes to recognize and have cordial relations with it.

\section{Conclusion}

Identity is the best tool of power elite to appeal and exploit forging relations across the board. The formation of the national identity from the boundaries marked amid 'self' and 'other' is vital in relationship between foreign policy formulation and identity. It is the power elite which play its role in articulation, interpretation, and operationalization of identity through the language of discourses that not only legitimize their actions but also get popular support among masses. Pakistan, soon after the partition of subcontinent, was faced with an issue of identity in the face of an existential threat from India. The external security threat coupled with bulging internal issues, forced Pakistan's power elite to steer its foreign policy using the language of Islamic identity. For years, owing to historical Indian vengeance, Pakistan sought cordial relations with the Muslim world. This helped Pakistan to not only resolve the identity crisis and unite a diverse social populace under the banner of Islam but also to mitigate many of its internal security issues, most prominently gaining economic security. However, the Indian hegemonic ambitions coupled with its growing animosity towards Pakistan forced the power elite to seek external security more vigorously. The reluctance of Muslim countries, to support Pakistan in the face of Indian threat, with which Pakistan had built strong ties over the course of its history led Pakistan to reshape its foreign policy. Indian Hindutva-led aims of regional dominance are only pushing Pakistan towards further security dilemma and securitization of its foreign policy in the $21^{\text {st }}$ century, compelling the power elite to search for new security alliances. 


\section{References}

Article 24. (1956). The Constitution of the Islamic Republic of Pakistan.

Article 40, (1973). The Constitution of the Islamic Republic of Pakistan.

Burke, S. M. (1973). Pakistan's Foreign Policy: An Historical Analysis. London: Oxford University Press.

Callard, K. (1957). Pakistan: A Political Study. George Allen \& Unwin.

Choudhury, G. W. (1969). Constitutional Development in Pakistan. Civil and Military Gazette.

Dar, S. A. (1986). Selected Documents on Pakistan's Relations with Afghanistan, 19471985. Islamabad: National Institute of Pakistan Studies Quaid-e-Azam University.

Haqqani, H. (2016). Pakistan: Between Mosque and Military. Gurgaon, Haryana: Viking.

Hassan, K. S. (1960). Pakistan and the United Nations. Manhattan Publishing Company.

Hussain, A. (1996). Pakistan Its Ideology and Foreign Policy. London: Frank Cass \& Co. Ltd.

Jones, R. W. (2004). Religious Radicalism and Nuclear Confrontation in South Asia. Delhi: Media House.

Katzenstiein, P. (ed). (1996). The Culture of National Security: Norms and Identities in World Politics. New York: Columbia University Press.

Khan, A. (1967). Friends Not Masters: A Political Autobiography. Karachi: Oxford University Press.

Khan, L. A. (1950). Pakistan: The Heart of Asia. Cambridge.

Kowalski, P. (2019). Turkish-Pakistani Relations: A Burgeoning Alliance?.Middle East Institute.

Kux, D. (2001). The United States and Pakistan, 1947-2000: Disenchanted Allies. Oxford: Oxford University Press.

Majlesi, F. (November 01, 2011). Pakistan, Setting the Region on Fire: Tracing the Historical Roots of Pakistan's Current Plight. Iranian Diplomacy. 
Musharraf, P. (2004, June 01). 'A Plea for Enlightened Moderation', The Washington Post. Retrieved on March 05, 2020 from https://www.washingtonpost.com/wpdyn/articles/A5081-2004May31.html

Muzaffar, M. Khan, I. Karamat, S. (2017). The Politics of Religious Legislation: A Case Study of Pakistan 1979-2000. Pakistan Social Sciences Review,1(2),1-12, doi:10.35484/pssr.2017(1-II)01

OIC Resolution. (1981). The Situation in Afghanistan. Resolution No. 3/3-P(IS).. Organisation of the Islamic Conference.

Pande, A. (2011). Explaining Pakistan's Foreign Policy: Escaping India. New York: Routledge.

Sattar, A. (1997). Afghanistan: Past, Present and Future, from jihad to Civil War. Islamabad: Regional Studies (IRS).

Siddiqui, A. R. (1996). The Military in Pakistan: Image and Reality. Lahore: Vanguard Books.

Smith, W. C. (1957). Islam in the Modern World. Current History. (52).190.

Takkar, M. K. (2016, July 13). Pakistan: Taliban Are "Our Boys". The Voice Times International. http:/ / www.thevoicetimes.com/pakistan-taliban-boys-2/

United Nations. (1968, February 19). Reports of International Arbitral Awards: The IndoPakistan Western Boundary (Rann of Kutch). between India and Pakistan (India, Pakistan)., Volume XVII. http://legal.un.org/riaa/cases/vol_XVII/1-576.pdf

White, M. B. (1949). Halfway to Freedom. New York: Simon and Schuster.

“On Spiritual and sentimental ties with Turkey." (1989). In Quaid-i-Azam Mohammad Ali Jinnah: Speeches and Statements 1947-48. Lahore: Research Society of Pakistan.

"President Musharraf Address to the Nation." (2001, September 19). Our LeaderMusarraf. https://presidentmusharraf.wordpress.com/2006/07/13/address-19september-2001/

"The Foreign Policy of Liaquat Ali Khan." (2010, October 17). Dawn.https:// www.dawn.com/news/881096/the-foreign-policy-of-liaquat-alikhan 